\title{
Visible minorities in remote areas: a comparative study of Roma in Hungary and Indigenous people in Australia
}

\author{
Andrew TAYLOR ${ }^{1}$, PAtrik TÁTRA I² and Ágnes ERÖSS ${ }^{2}$
}

\begin{abstract}
The present study argues that Hungarian Roma and Australian Indigenous are non-immigrant visible minorities which are overrepresented and concentrated in remote areas. Based on this premise, we investigate and compare the general living circumstances and socioeconomic status of these visible minorities. The key hypothesis is that visible minorities living remotely face common social, economic, demographic and political difficulties compared to the dominant majority in developed countries. This hypothesis is examined by analysing and comparing a range of statistical indicators for fertility, health, education, labour market, income and living conditions. We found that, independent from the geographical location and the social context, patterns of social and spatial exclusion are alike across the studied developed nations. The data show there are substantial gaps in fertility, health, education, income, labour market, household internet and car ownership indicators between visible minorities and the majority society. Furthermore, gaps exist between remote living and non-remote people as well. Overall, the disadvantaged position of Roma and Indigenous people can be grasped along three dimensions: spatial remoteness, socioeconomic remoteness and ethnic differentiation.
\end{abstract}

Keywords: visible minorities, remoteness, social exclusion, peripheralization, Australia, Hungary

\section{Introduction}

In developed nations substantial regional disparities in living standards, health indicators and general wellbeing persist, with remote or peripheral areas faring most poorly relative to others (TAYLOR, A. et al. 2011; LANG, T. 2015; NAGY, E. 2015). Both regional disparities and social exclusion are commonly discussed as issues in contemporary social sciences literature, but research relating the two is rather limited, despite social exclusion invariably characterizing peripheral populations (Bock, B. et al. 2014). In remote areas of developed countries, disparities between the socio-economic status of sub-populations (e.g. titular/ majority vs. minority ethnic groups) are in many cases extreme (see for example, AвUSaAd, I. and Creamer, C. 2012; Australian Government 2015; WANG, J-H. 2015).
Generally, 'visible minorities' living in remote areas face similar problems in terms of sub-standard living circumstances in fields such as education, employment, health status and wealth accumulation. In remote areas, opportunities for transitioning socio-economically in situ, as opposed to leaving the region temporarily or permanently, can be limited. Economic and other theorists have suggested that, under conditions of a bifurcated society, gaps between the 'have's' and 'have not's' tend to increase (TAYLOR, A. et al. 2011). This contributes to the dual effect of those remaining in such locations having neither the social or other capital to move to areas where they might be able to improve their socio-economic lot (i.e. they become 'stuck') and the inter-generational occurrence of poor social conditions, resulting in long lasting negative effects. These ongoing

\footnotetext{
${ }^{1}$ Northern Institute, Charles Darwin University. 0909 Darwin, Australia. E-mail: andrew.taylor@cdu.edu.au

${ }^{2}$ Geographical Institute, Research Centre for Astronomy and Earth Sciences of the Hungarian Academy of Sciences. H-1112 Budapest, Budaörsi út 45. E-mails: tatrai.patrik@csfk.mta.hu, eross.agnes@csfk.mta.hu
} 
issues have and continue to be the focus of special or targeted development policies and programs by governments (for example, KIM 2011; Australian Government 2015).

In this paper we use the term 'visible minority' to describe the status of Roma in Hungary and Australian Indigenous reflecting their ethnic/racial differentiation and their social exclusion in both countries. The term originally emanated as a Canadian statistical category for non-white groups calling attention to their disadvantaged socio-economic position and discrimination against them in the labour market. Members of visible minorities were defined as "...persons, other than Aboriginal peoples, who are non-Caucasian in race or non-White in colour" (Hou, F. and Рісот, G. 2004, 9). In the Canadian context, the term reflected the increasing and changing nature of migration (especially the growing numbers of non-European immigrants), with the main cultural cleavage previously based on linguistic and religious characteristics, which are inconspicuous or 'invisible'. A similar term, 'person of colour' is applied in the United States to all non-White groups. While this term is not a statistical category, the concept reflects the hierarchical racial categories, where the reference colour is the white and therefore non-Whites become racialized (GALABUZI, G. 2006; White, P.A. 2008).

In Australia, public policy in relation to immigration and society has promoted the nation as culturally pluralistic and tolerant, and overseas migration contributes a substantial portion of national population growth. In 2014-2015, for example, 53 per cent of the nation's population growth came from immigration (ABS 2015). The most overt labelling of non-white residents has been applied to Australia's original inhabitants, for whom there is a history of negative stereotyping (Pedersen, A. and Walker, I. 1997). In East Central European and especially in Hungarian context, the term 'visible minority' is appropriate for Roma as they have been a part of the population for many generations and are the only visibly different group of significant size. Their members are usually exposed to ethnic distinctions, face stigmatization and discrimination in many fields of the life (Molnár, E. and Dupcsik, C. 2008).

In light of this context, the term 'visible minority' refers in this study to those groups (Aboriginal and Roma) whose members have a different skin tone or lineament to the majority society, but have no migrant background. ${ }^{3}$ Although these groups are autochthonous, however, with significant differences regarding their autochthony, they remain excluded from the white majority society as inherited from the colonial era. In post-socialist Central and Eastern Europe (including Hungary), as in the Canadian case, the traditional divisions evolved along linguistic lines so the only traditional visible minority are the Roma, who generally adopted the local majority society's language and religion. We argue that using the term 'visible minority' is appropriate to describing the contemporary social, economic and community status of the two groups as distinct them from other minorities with migrant backgrounds.

Although there are attempts in the literature to reveal the relationships between remote living visible minorities and substandard living circumstances, these papers generally focus on the national or subnational level (e.g. Virág, T. 2006; PÁsztor, I.Z. and PÉnzes, J. 2012), and the range of literature documenting regional disparities through the comparison of minority residents from non-adjacent nations is less comprehensive. Only a few studies apply crosscountry comparison in order to provide a better understanding of the interconnection between some aspects of ethnicity, peripheralization and social-economic exclusion (e.g. Gregory, R. and Daly, A. 1997; LAdÁNYI, J. and Szelényi, I. 2001; Milcher, S. 2006; LeE, K.W. 2011).

\footnotetext{
${ }^{3}$ Naturally, Roma, migrated to Central and Southeast Europe since the late Middle Ages, is literally a migrant ethnic group who cannot be described as 'indigenous', still, the term 'non-migrant background' expresses the long-rooted presence of Roma in this region.
} 
We use the comparison of Hungarian Roma with Australian Indigenous people in remote areas to demonstrate the above interconnectedness. Australia and Hungary are non-adjacent, developed nations with significant differences in their size, economics, political systems, societies and economies. However, by comparing and contrasting the socio-economic characteristics of Roma and Australian Indigenous people we attempt to present that peripheralization and marginalization are common phenomena for nonmigrant visible minorities, in spite of specific national contexts and different geographical scale. We also claim that the two societies are connected by similar basic social standards, living circumstances and health conditions.

From the point of view of spatiality, we also argue that Hungarian Roma and Australian Indigenous are overrepresented and concentrated in remote areas. Based on this premise, we investigate and compare the general living circumstances and socioeconomic status of these visible minorities. In doing so, we aim to explore the relationship between remoteness, marginalization and social exclusion for these groups. Comparing visible minorities' position along three dimensions (spatial remoteness, socio-economic status and ethnic differentiation) we intend to reveal whether the two countries with significant differences in geographical, demographical, socioeconomic and political characteristics show similarities and the types and extent of these where they exist.

\section{Who are Roma/Australian Indigenous people?}

The groups which are the focus in this paper, the Roma and Australian Indigenous people, are defined differently, making the question of 'who are Roma or Indigenous' key. The question incorporates both theoretical and practical elements. The former is primarily important for the academic sphere, while exact definitions are required in other areas to improve the effectiveness of programs supporting
Roma (Fleck, G. and Messing, V. 2010) or to assist in defining the scope Indigenous people eligible under land rights legislation (for example, TAyLor, A. and Bell, B. 2013).

The Roma issue has been highly politicized in the last decades in post-socialist countries, thus, the number of Roma is a debated issue not only among scholars but among the public and politicians as well. The number of ethnic Roma by self-identification (for example, the numbers provided in censuses) has always been far fewer than the number of Roma estimated by experts (see e.g. Kocsis, K. and Kovács, Z. 1991; LAdÁNYI, J. and SzelÉNYI, I. 2001; Kemény, I. and JANKY, B. 2005; HablicseK, L. 2008; PÁsztor, I.Z. et al. 2016). Consequently, census results regarding the number of Roma have been considered 'unreliable' and, in order to fill the gap, there have been many surveys to measure their numbers and characteristics since the 1970s. Most have classified someone as Roma according to way of life and physical appearance, as well as by ethnic descent (KEMÉNY, I. and JANKY, B. 2005) claiming that Roma ethnicity and social stratification can be surveyed by applying clear methods (Havas, G. et al. 2000, 194). However, ethnicity and ethnic groups are conceived as a social construct by other scholars who claim that surveys cannot objectively report the number of Roma because the survey method based on external classification reveals more about the classifiers than the subjects (LADÁNYI, J. and SZELÉNYI, I. 2001).

Being aware of the above mentioned debates about the number of Roma, in this study we use the ethnic data from the Hungarian census based on self-identification. First, this is the only available dataset for the number of Roma in the level of settlements; second, the methodology of census (self-identification) is more appropriate than diverse methodologies of external ethnic classification; and third, this dataset represents those living in poverty and exclusion, but underrepresents upwardly mobile Roma people with successful integration strategies. Thus, this dataset can be used efficiently to define the number and territorial distribution 
of population subject to receive social transfers (LADÁNYI, J. and ViRÁG, T. 2009).

In modern times, the term Indigenous or First Australian refers to those people who have self-identified as being of either of Aboriginal or Torres Strait Islander origin in relevant data collections such as the fiveyearly Census. In similarity to the Roma, representation in official statistics by self-identification makes Indigenous status a social construct (Rowse, T. 2006). The contemporary use of self-identification differs from the postcolonial and subsequent periods up the 1970s during which times First Australians were distinguished as 'natives' based on the proportion of patrimonial lineage. For example, in the Australian Census right up until the 1970s, the term 'native' was used to distinguish individuals with a certain percentage of direct Indigenous lineage (often labelled 'full blood') while those with less were considered to be 'mixed race' and outcasts (often labelled 'halfcast'). Natives were subsumed under protection acts, which sought to assimilate them into white society. The most blatant marker of the assimilation era was the forced removal of children from their families into the 'care' of missions and other organisations, a practice which continued right up until the 1970s.

In recent decades, successive national governments have established legislation, policies and programs to recognise Indigenous people as traditional owners of the lands and to improve their socio-economic status. As a result, Indigenous Australian's have obtained gains in the areas of land rights and land ownership, as well as improvements in key quality of life indicators like life expectancies and socio-economic status (Australian Government 2015). This has generated significant increases in self-declarations and therefore high population growth for this minority group (Hoddie, M. 2006).

\section{Methods}

The key hypothesis of this study is that visible minorities living remotely face similar difficulties with common social, economic, demographic and political positions compared to the dominant majority in developed countries. However, defining where or who is remote depends on local, national and international contexts, and accordingly definitions and the application of these vary between nations and continents. Thus, a basic question of this study is how to define remoteness in the two countries under study.

In Australia, remoteness is primarily analysed in spatial terms. The size and low population density of the Australian continent means that substantial proportions of the landmass can be considered as remote (Figure 1). For the collection and dissemination of official statistics, and policy and program initiatives with specific redress to remote populations, the classification of remoteness is based on the Accessibility/ Remoteness Index of Australia, known as ARIA+. This provides an accessibility score to each populated locality based on road distances to five levels of service centres. The locality indexes are interpolated to provide a remoteness index value for one-kilometre grids of the continent (Australian Population and Migration Research Centre 2014).

In Hungary, the relatively small size of the landmass means most of the countryside is accessible in few hours from the capital Budapest. Nevertheless, both the literature and governmental policies define remoteness based on economic, social and demographic indicators (FAluvégI, A. and Tipold, F. 2012; PÉnzes, J. 2013). These collectively delimit the underdeveloped regions with complex economic and social disadvantages as being remote. As a consequence, geographical peripheries measured by accessibility and backward areas measured by complex economic-social indices are highly overlapping in Hungary (Lốcsei, H. and SzALKaI, G. 2008), and on that basis it may be argued as being remote. Thus, we define remote areas in Hungary as those suffering from both social, economic and infrastructural backwardness as well as high unemployment (thus, receiving dedicated state financial support). 


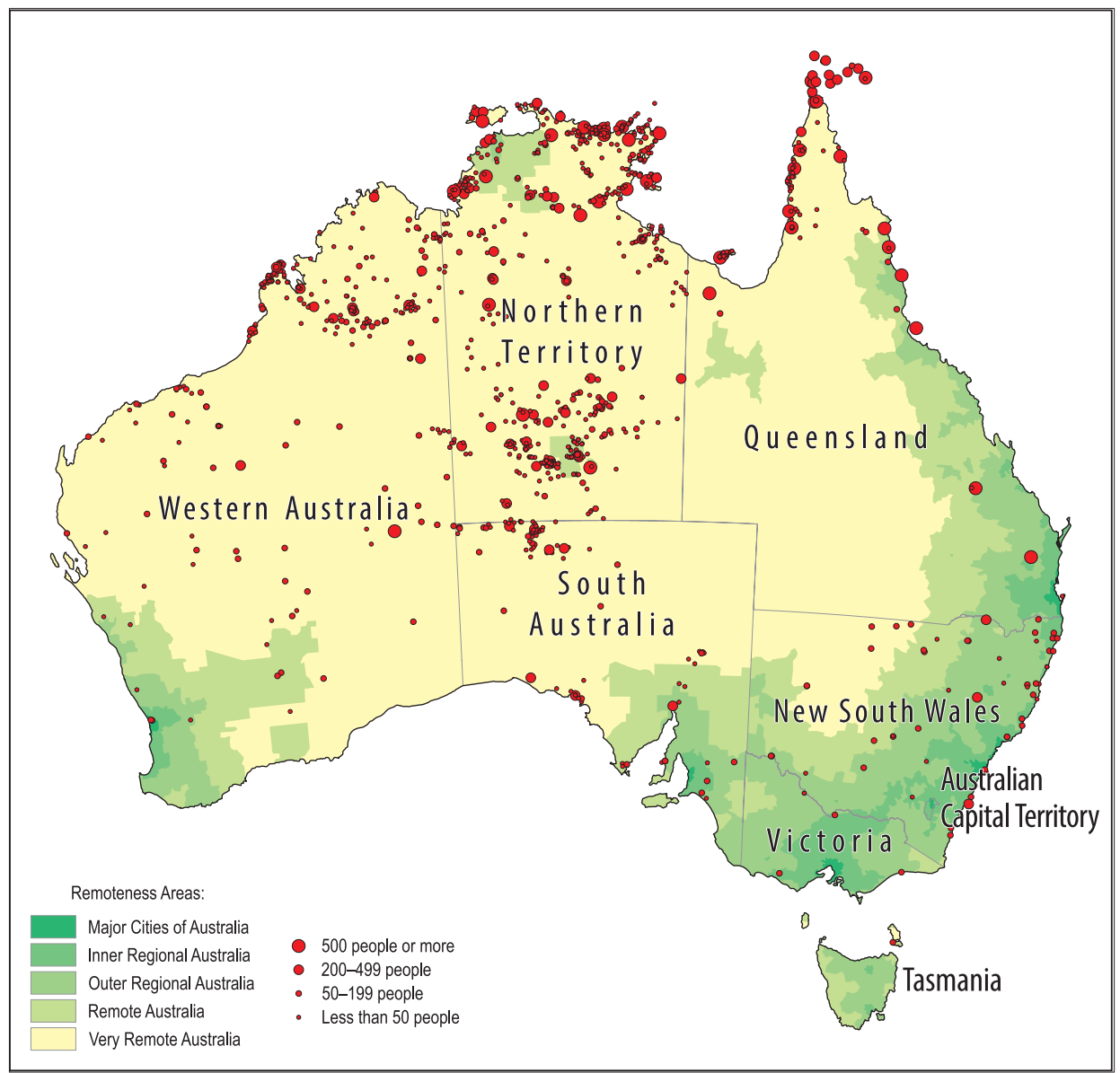

Fig. 1. Australia's remoteness areas and Indigenous communities. Circles indicate relative size of Indigenous communities. Source: ABS 2007.

These areas cover mostly the north-eastern and south-western peripheries and some adjoining inner peripheries (Figure 2).

While the contexts for remoteness in Australia and Hungary differs similar living circumstances prevail for Roma and Indigenous populations making remoteness a suitable lens for comparing and contrasting visible minorities.

The verity of this key hypothesis is examined by analysing and comparing a range of statistical indicators. Data includes comparisons and investigation of fertility, health, education, labour market, income and living conditions. We compare and contrast indicators between the two groups, between remote and non-remote areas and between visible minorities and others. This comparison should underpin that (1) visible minorities live under worse circumstances than the dominant ethnic group (both in remote and non-remote areas), (2) remote living visible minorities face more significant challenges in various facets (access to health care, employment, education, etc.) compared to non-remote co-ethnics, and (3) visible minorities in remote areas across developed nations can be characterized by similar attributes described by similar values of indices. 


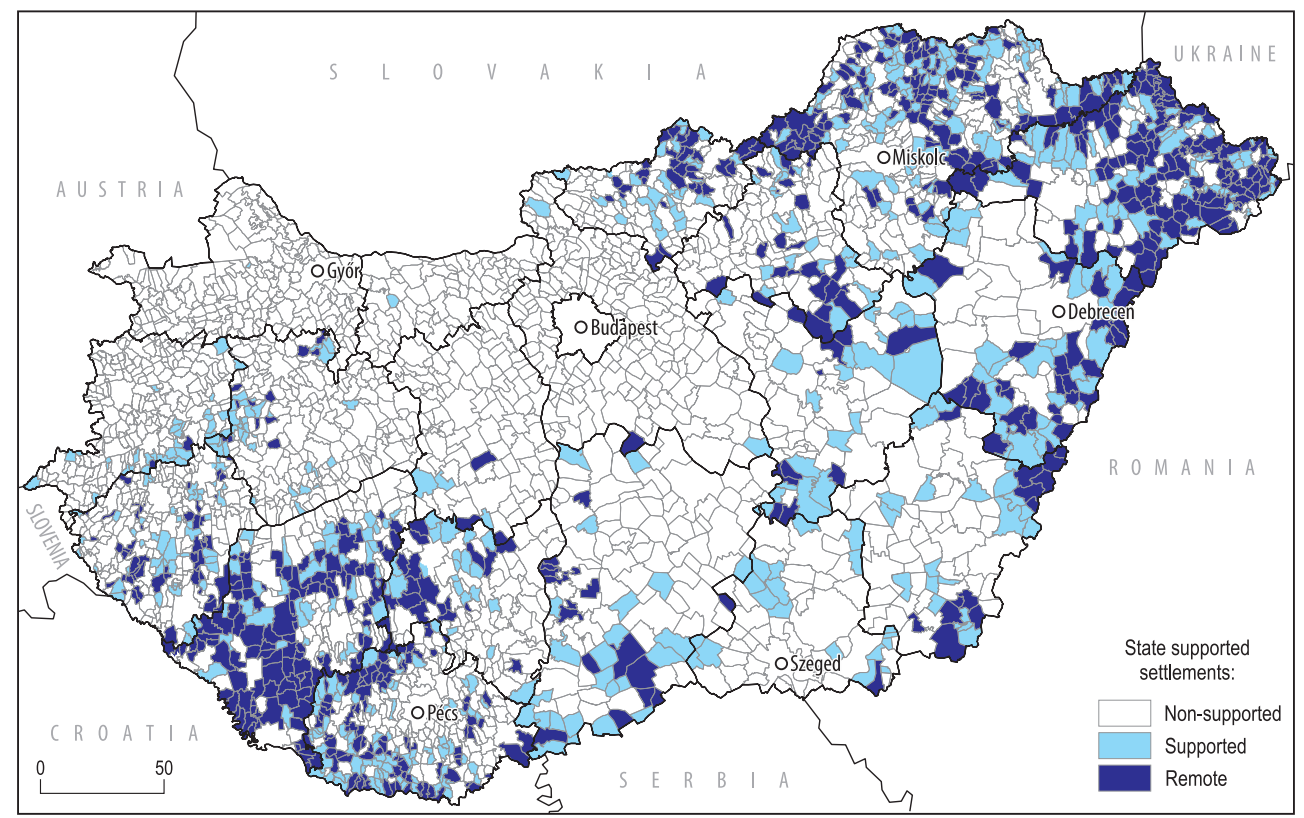

Fig. 2. State supported areas in Hungary. Source: Authors' edition based on the 105/2015 (IV. 23.) Government Regulation.

Data for Roma are limited; beside the available census data on the national level indicated as 'Roma average' in the tables, detailed territorial data for Roma is not accessible. Consequently, an indirect analysis is applied. This includes presenting the indicators from the 2011 Census for remote areas by settlement categories classified by the share of Roma in the total population. Analysis of the demographic distribution and socio-economic situation for Australian Indigenous people in remote areas are primarily based on 2011 Census data.

We constructed custom data tables using the software ABS Table Builder. We also used data from a range of other collections including the National Aboriginal and Torres Strait Islander Social Survey and a range of demographic collections provided by the Australian Bureau of Statistics (ABS). Data sources are denoted next to relevant results.

\section{Results}

Number and territorial distribution of Roma and Indigenous people

According to the 2011 census in Hungary, the number of ethnic Roma population, based on self-identification, increased by 63 per cent in ten years to 309,000 persons. The aggregate number of those who declared Roma affiliation ${ }^{4}$ exceeded 315,000 persons or 3.2 per cent of the total population. ${ }^{5}$ As it is possible to

\footnotetext{
${ }^{4}$ Based on at least one of the census categories reflect ethnic belonging. These are ethnicity, mother tongue and spoken language.

${ }^{5}$ According to surveys, Roma in Hungary counted around 600,000 in the first half of the 2000s (KEMÉNY, I. and JANKY, B. 2005). Nowadays, their number approaches the 700,000 (HABLICSEK, L. 2008), or, based on the detailed territorial data by PÁszTor, I.Z. et al. (2016), can reach 870,000.
} 
declare multiple ethnic identities since the 2001 census, most of those expressing Roma affiliation self-identified Roma and Hungarian ethnicity simultaneously. At the same time, only 54,000 persons declared Roma mother tongue due to their long-standing linguistic assimilation. ${ }^{6}$

The salient increase in the number of Roma in the recent decades is the consequence of both the above-mentioned changes in census methodology, and the high fertility rate of the Roma outstripping the respective data of any other ethnic groups. However, the growth in their number was much higher than their estimated fertility would have generated (HablicseK, L. 2008), thus, we argue that the census number of Roma depends primarily on the subjective nature of self-identification influenced by the diverse Roma identity constructions and the contemporary social conditions (including their stigmatized being, discrimination, etc.) (CSEPELI, G. and Simon, D. 2004; TÁtrai, P. et al. 2017).

The majority of Roma (53\% and much higher than for the total population at 31\%) live in rural areas in the country although to a decreasing extent since internal migration flows are towards urban areas (PÉNZES, J. et al. 2018). Additionally, a significant number of Roma live in municipalities with less than 500 inhabitants, where living circumstances are at their worst in the Hungarian context. Furthermore, residential segregation and the peripheral geographical location of villages with high Roma populations also contributes to segregation (LadánYI, J. and SZelÉNYI, I. 2001) based on segregated settlements within the locality or a ghettoized villages, particularly in the north-eastern and south-western peripheries (Kocsis, K. and KovÁcs, Z. 1991; VIRÁG, T. 2006). Despite these issues, the proportion of the Roma within the municipalities is still quite low. Although migration and urbanization process have reshaped their geo-

\footnotetext{
${ }^{6}$ Already the 1971 national survey documented that Hungarian is the mother tongue of about 70 per cent of the Roma (KEMÉNY, I. and JANKY, B. 2005). According to the 2011 census only about quarter of the Roma can speak one of the Roma dialects.
}

graphical distribution, the ethnic geography of Roma has hardly changed in the last hundred years. About 60 per cent of the Roma live in Northeast and Southwest Hungary which coincides with the regions with high number of small villages. Because of urbanisation in the second half of the $20^{\text {th }}$ century, a significant number of Roma live in the central region, in the Budapest agglomeration.

Comparing the share of Roma with the remoteness on the level of localities we found significant overlap (Figure 3). Although "only" 30.4 per cent of Roma live in territories considered as remote, this is much higher than the respective data of total population (6.3\%). Likewise, Roma constitute 14.9 per cent of total remote population, while the national average is only 3.1 per cent. The above data refers to Roma's concentration and overrepresentation in remote areas (Table 1).

The 2011 Census count of Indigenous people in Australia was 548,369, or 2.5 per cent of the national population (ABS 2016). In the 2006 Census, the count was 455,031 Aborigines and Torres Strait Islanders, a 20 per cent growth in number in five years. Two-thirds of this growth was through demographic factors (natural increase) and one-third by the changing identifications (ABS 2013a). ${ }^{7}$ In 2011, around 130,000 (22\%) lived in remote areas where they comprised a quarter of the population (ABS 2016). In some remote areas there are high concentrations of Indigenous Australians, notably in and around discrete remote communities found across in the North of the country (denoted by the black dots in Figure 1).

Nevertheless, Indigenous population growth in urban areas in the South of the country is far outstripping growth in remote areas (TAYLOR, A. and BELL, B. 2013), and eroding the remote share significantly. During 2006 to 2011, for example, the Indigenous population of northern Australia grew by 12 per cent compared to 24 per cent for the

\footnotetext{
${ }^{7}$ Similarly to the Roma case, estimates highly rose Indigenous number both in 2006 (517,000; 14\% difference compared to census) and 2011 (670,000; 22\%) (ABS 2013a).
} 


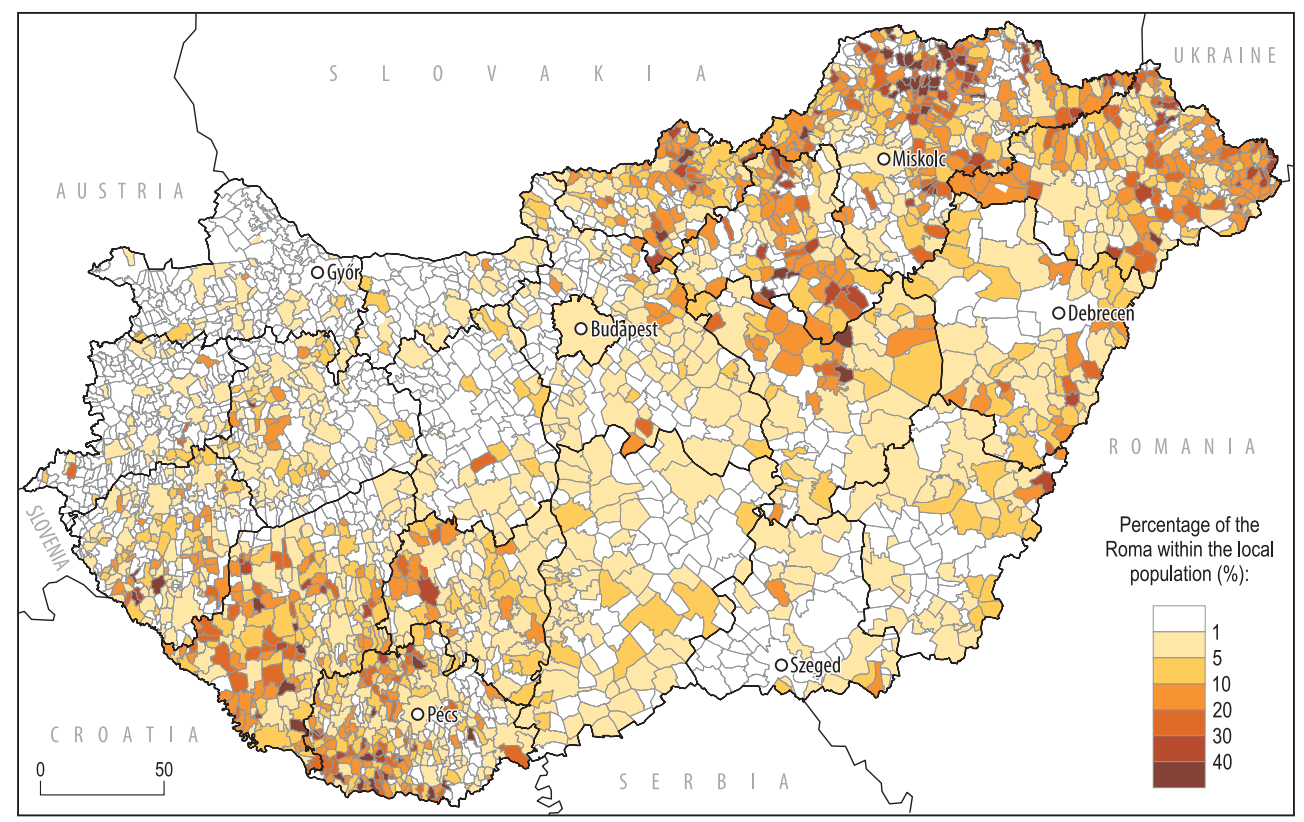

Fig. 3. Territorial distribution of the ethnic Roma population in Hungary (2011). Source: Authors' edition based on the 2011 Census data.

Table 1. Settlement data on remote areas in Hungary, 2011

\begin{tabular}{c|c|c|c|c|c}
\hline $\begin{array}{c}\text { Proportion } \\
\text { of Romas in } \\
\text { settlements, \% }\end{array}$ & $\begin{array}{c}\text { Number of } \\
\text { municipalities }\end{array}$ & $\begin{array}{c}\text { Average size of } \\
\text { municipalities, } \\
\text { persons }\end{array}$ & $\begin{array}{c}\text { Population in } \\
\text { 2011, persons }\end{array}$ & \multicolumn{2}{|c}{$\begin{array}{c}\text { Population change in } \\
\text { per cent }(1990=100 \%)\end{array}$} \\
\cline { 5 - 6 } & & 355 & 26,622 & $1990-2001$ & $2001-2011$ \\
\hline $0-1$ & 75 & 929 & 106,851 & 91.0 & 86.6 \\
$1-5$ & 115 & 949 & 115,785 & 98.5 & 90.7 \\
$5-10$ & 122 & 1,249 & 216,072 & 98.4 & 91.3 \\
$10-20$ & 173 & 1,078 & 101,293 & 101.7 & 94.5 \\
$20-30$ & 94 & 890 & 40,036 & 102.8 & 98.3 \\
$30-40$ & 45 & 636 & 24,178 & 107.2 & 99.8 \\
40 and over & 38 & 953 & 630,837 & 98.7 & 92.7 \\
Total remote & 662 & 3,735 & $9,306,791$ & 98.3 & 97.8 \\
Total non-remote & 2,492 & - & 308,957 & 133.2 & 162.6 \\
Roma average & - & &
\end{tabular}

Source: Authors' calculation based on the 2011 Census data.

southern Australia. There are a number of complex and interconnected explanations for this. Firstly, progressively more people in southern parts are identifying as Indigenous (when they did not previously) as societal ac- ceptance has improved. Secondly, high rates of mixed patterning in southern cities (where one person in the relationship is Indigenous but the other is not), which invariably leads offspring being declared as Indigenous on 
the birth certificate. Migration from North to South and changing Census procedures and population estimation methods are also contributing (TAYLOR, A. and BELL, B. 2013).

Despite the governmental policies to improve conditions for Australia's Indigenous population since the 1980s resulting in improving life quality indicators and growth in numbers, there remain significant gaps in the socio-economic status of Indigenous and other Australian's. Similarly, health indicators highlight there are gaps in key indicators remaining (Australian Government 2015). In remote and northern areas, these gaps are far higher, although difficult to measure accurately, despite concerted policies and programs being in place for a number of decades aimed at reducing such gaps.

The spatial distribution of Indigenous Australians, against many preconceptions, is towards the urban areas in the more populous States (TAylor, A. and Bell, B. 2013). However, in proportional terms, concentrations in the population are far higher outside of large urban centres and particularly in the remote regions of the nation (Figure 4). This shows a similar pattern to Roma in Hungary as far as there is an inverse relationship between the proportion of the population which is Indigenous for individual communities and the size of these (Table 2). However, Indigenous representation in remote Australia is far higher than for Roma with around half of all communities having a 50 per cent or greater Indigenous share in their population.

\section{Results for comparative statistical indicators}

The demographic indices for the Roma are considerably different from non-Roma in Hungary and throughout Central and Eastern Europe. Roma is the only ethnic group in Hungary characterized by high fertility rates, positive natural growth and young age structure (with an average age 15 years lower than the total population) (TÁtrai, P. 2015). Although fertility rates for Roma are

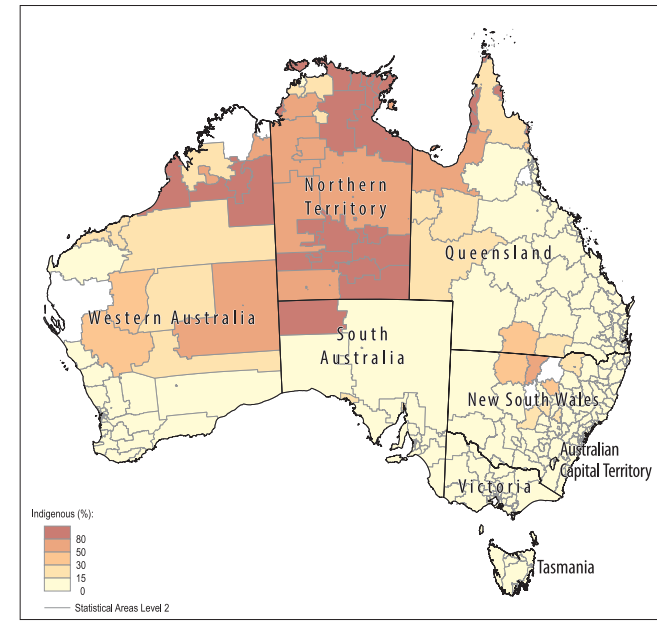

Fig. 4. Proportion of the population who identified as Indigenous in 2011. Source: Custom data extracted by the authors from ABS Table Builder, 2011 Census.

Table 2. Settlement data for remote Indigenous Australians, 2011

\begin{tabular}{c|c|c}
\hline $\begin{array}{c}\text { Proportion of } \\
\text { Indigenous, } \%\end{array}$ & $\begin{array}{c}\text { Number of } \\
\text { communities }\end{array}$ & $\begin{array}{c}\text { Average size } \\
\text { in persons }\end{array}$ \\
\hline $0-10$ & 71 & 1,809 \\
$10-30$ & 57 & 3,407 \\
$30-60$ & 40 & 1,145 \\
$60-85$ & 35 & 2,651 \\
$85-95$ & 112 & 1,693 \\
95 and over & 89 & 10,106 \\
Total remote & 404 & 3,832 \\
Non-remote & 710 & 28,585 \\
\hline
\end{tabular}

Source: Custom data extracted by the authors from ABS Table Builder, 2011 Census.

still much higher than the national average (Table 3), they have been slowly decreasing for decades (KEMÉnY, I and JANKY, B. 2005). ${ }^{8}$

Comparing the elements of natural growth in remote and central parts of the country, both birth and death rates are higher in remote areas. Throughout the country, higher Roma share is associated with higher fertility and lower death rate. The latter can be explained by the low number of elder Roma age

\footnotetext{
${ }^{8}$ Some studies call attention to the possible interrelation between high fertility and the residential segregation of Roma (e.g. JANKY, B. 2006; LADÁNYI, J. and SZELÉNYI, I. 2006; DURST, J. 2010).
} 
Table 3. Main demographic indicators of remote and non-remote areas in Hungary, 2011

\begin{tabular}{c|c|c|c|c|c|c}
\hline \multirow{2}{*}{$\begin{array}{c}\text { Proportion } \\
\text { of Romas in } \\
\text { settlements, \% }\end{array}$} & $\begin{array}{c}\text { Annual live } \\
\text { birth rate }\end{array}$ & $\begin{array}{c}\text { Annual } \\
\text { death rate }\end{array}$ & $\begin{array}{c}\text { Annual } \\
\text { natural } \\
\text { increase } \\
\text { rate }\end{array}$ & $\begin{array}{c}\text { Annual net } \\
\text { migration } \\
\text { rate }\end{array}$ & $\begin{array}{c}\text { Ageing } \\
\text { index }\end{array}$ & $\begin{array}{c}\text { Live birth } \\
\text { per } 100 \\
\text { women } \\
\text { aged 15-x } \\
\text { years }\end{array}$ \\
\cline { 2 - 5 } $0-1$ & 8.0 & 17.5 & -9.5 & -4.0 & 190 & 183 \\
$1-5$ & 10.1 & 16.4 & -6.3 & -2.9 & 150 & 182 \\
$5-10$ & 10.7 & 17.1 & -6.3 & -2.2 & 131 & 184 \\
$10-20$ & 12.4 & 15.1 & -2.7 & -4.6 & 112 & 187 \\
$20-30$ & 14.2 & 13.4 & 0.8 & -5.7 & 87 & 199 \\
$30-40$ & 16.1 & 13.1 & 2.9 & -4.6 & 67 & 211 \\
40 and over & 20.0 & 12.0 & 8.0 & -8.2 & 45 & 221 \\
Total remote & 12.3 & 15.3 & -3.0 & -4.2 & 111 & 190 \\
Roma average & - & - & - & - & 14 & 233 \\
\hline
\end{tabular}

Source: Authors' calculation based on the 2011 Census data.

groups. ${ }^{9}$ Consequently - the unfortunately unavailable - age-specific death rates would be the adequate index to describe Roma mortality. ${ }^{10}$ Using data of settlements with more than 40 per cent Roma population as proxy for Roma suggests there are no significant differences in Roma demography between remote and non-remote areas (Table 3). While municipalities with Roma local majority are characterized by the highest natural growth, they also have the highest migration loss due to their unfavourable position in the settlement hierarchy and the poor economic opportunities. Furthermore, the high (and rising) share of Roma can speed up emigration of the young, well-educated, non-Roma people with higher human capital, which is partly counterbalanced by the immigration of poor people, mostly Roma (VIRÁG, T. 2006).

Fertility rates for Indigenous Australians are also much higher than for the general population. In 2014 the national Indigenous total fertility rate was 2.22, compared to 1.87 for the overall population (ABS 2015). The median age of Indigenous mothers, at 24.5 years, was much lower than the overall population for whom the median age was 30.8 in 2014.

\footnotetext{
${ }_{9}^{9}$ Only 4.6 per cent of the Roma population is aged 60 years or over (Hungary's average: $23.5 \%$ ).

${ }^{10}$ For instance, surveys indicate much higher infant mortality compared to the national population average (EC 2014).
}

Babies born to Indigenous mothers are twice as likely to be of low birthweight and, while there have been large declines in Indigenous infant mortality rates in the past four decades, they remain at almost twice that of non-Indigenous infants. Separate fertility data is only available at the State and Territory level in Australia, however, using the Northern Territory as a proxy for remote Australia suggests Indigenous fertility in remote areas to be around the same (2.1) as for Indigenous people across Australia as a whole.

Health indicators and surveys report on Roma's poor health condition and poor access to healthcare (e.g. BABUsiк, F. 2004; FónAI, M. et al. 2008; EC 2014). Based on the only available health related indicator for Roma, there is a broad gap between Roma's and non-Roma's life expectancy of about ten years less for Roma (BABUSIK, F. 2004; EC 2014). This is far more than the regional gap in life expectancy (6.5 years) seen between the best (Central) and the worst (Northeast) regions. The literature highlights the strong impacts of low education levels, low incomes, high unemployment rate and high share of Roma population on low life expectancies (Klinger, A. 2003; Uzzoli, A. 2016).

The health status for Australian Indigenous people, especially those in remote areas, is significantly worse than for others. Life expectancy estimates are a prime example with 
estimates suggesting a twelve-year gap for males and an eleven-year gap for females (Table 4). Indigenous life expectancies outside of Australia's major cities are estimated at 67.3 years for males and 72.3 years for females (ABS 2013b). Detailed data for remote areas are not compiled due to issues with the registration of Indigenous deaths in some States. Nevertheless, data demonstrate Indigenous Australians die at younger ages and higher rates than non-Indigenous Australians, with 65 per cent of Indigenous deaths occurring prior to age 65 compared to only 19 per cent for non-Indigenous deaths (AIHW 2014). The main causes of life expectancy gaps between Indigenous and nonIndigenous Australians are chronic diseases including circulatory disease $(24 \%$ of the gap), endocrine, metabolic and nutritional disorders $(21 \%)$, cancer $(12 \%)$, and respiratory diseases (12\%) (AIHW 2014).

Since poor health status is interrelated to low education levels, it is not surprising that the Roma population has low educational attainment. More than 80 per cent attended only primary school, while an incredibly low 1.2 per cent has a higher school qualification. These figures are reaching far behind the national and the remote average. Comparing the total population of remote and nonremote areas shows a significant gap with much better values for the non-remote population (Table 5) with a higher Roma proportion correlating with worse educational indices in both areas.

In remote Australia there is also a strong positive correlation $\left(r^{2}=.82\right)$ between the proportion who are Indigenous in settlements and the proportion of Indigenous who did not attend school (Figure 5). For example, a much higher percentage of adults did not go to school in settlement with more than 95 per cent indigenous residents.

Conversely, an inverse relationship is observed between the proportion of residents who are Indigenous in settlements in remote

Table 4. Life expectancy estimates for Indigenous and other Australians, 2010-2013

\begin{tabular}{l|c|c|c|c|c|c}
\hline \multirow{2}{*}{ Level, cities } & \multicolumn{2}{|c|}{ Indigenous } & \multicolumn{2}{c|}{ Other Australians } & \multicolumn{2}{c}{ Indigenous life } \\
\cline { 2 - 6 } & Males & Females & Males & Females & Males & Females \\
\hline National level & 67.4 & 72.3 & 79.8 & 83.2 & 12.4 & 10.9 \\
Outside of major cities & 67.3 & 72.3 & 80.7 & 84.7 & 13.4 & 12.4 \\
Major cities & 68.0 & 73.1 & 81.7 & 85.0 & 13.7 & 11.9 \\
\hline
\end{tabular}

Sources: ABS 2012a and ABS 2013b.

Table 5. Population aged 7 years or older by the highest education completed in Hungary, 2011

\begin{tabular}{c|c|c|c|c}
\hline \multirow{2}{*}{$\begin{array}{c}\text { Proportion } \\
\text { of Romas in } \\
\text { settlements, } \%\end{array}$} & \multicolumn{3}{|c}{ Share of population aged 7 years or older completed } \\
\cline { 2 - 5 } & at most primary school, $\%$ & \multicolumn{2}{c}{ higher education, $\%$} \\
\hline $0-1$ & 55.9 & Non-remote & 4.2 & 15.1 \\
$1-5$ & 55.5 & 35.7 & 5.1 & 18.6 \\
$5-10$ & 57.8 & 33.5 & 4.6 & 8.2 \\
$10-20$ & 57.7 & 47.3 & 5.0 & 7.8 \\
$20-30$ & 63.4 & 50.4 & 3.1 & 4.9 \\
$30-40$ & 69.1 & 56.6 & 2.0 & 1.9 \\
40 and over & 77.2 & 65.3 & 4.6 & 16.3 \\
Total & 59.6 & 77.8 & & 1.2 \\
\hline
\end{tabular}

Source: Authors' calculation based on the 2011 Census data. 
areas and the proportion that have a postschool qualification equivalent to a Bachelors level or higher (Figure 6).

The 2011 census data for Hungary also show the disadvantageous position of the Roma in the labour market. The employment rate among Roma is 25.1 per cent, while the national average is double at 57.9 per cent. The remote area's average is in between the two values $(42.5 \%)$. These, however, should be treated cautiously since in remote areas, and especially small villages, economic activity is partly realized in the grey and black economy. Thus, statistical data regarding employment and income reflects worse situ-

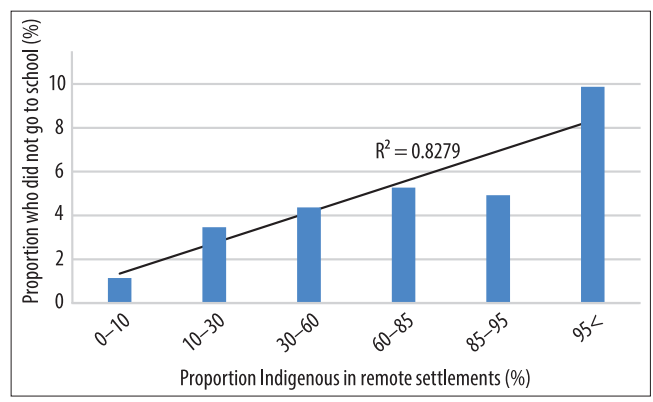

Fig. 5. Did not attend school by proportion Indigenous in remote settlements, 2011. Source: Custom data extracted by the authors from ABS Table Builder, 2011 Census.

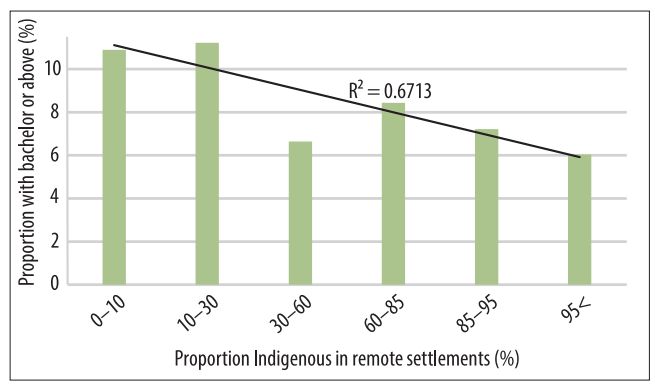

Fig. 6. Bachelor degree level or higher post-school qualification by proportion Indigenous in remote settlements, 2011. Source: Custom data extracted by the authors from ABS Table Builder, 2011 Census. ation than the reality (FEISCHMIDT, M. 2012) ${ }^{11}$ The official data on unemployment show the same pattern (Table 6).

The unemployment rate for the Roma is almost four times higher than the national average. This difference would be much higher without public work, which is counted in statistics as normal employment. Public work dominates the labour supply in remote areas and especially in those municipalities with high proportion of Roma, but still many remote living Roma families subsist without employed family member. The joint presence of high unemployment and low activity among the Roma results in high number of inactive and dependent Roma population.

Australian Indigenous unemployment rates are higher in remote areas and higher for settlements where a greater proportion of residents are Indigenous (Figure 7). Conversely, Indigenous participation rates (those either working or actively seeking work) are higher at remote settlements with a lower proportion of Indigenous residents in the population.

At communities with higher proportions of Indigenous residents, employed people are more likely to work in the government sector (Table 7) with a third of employed Indigenous residents work in the government sector compared to a fifth in non-remote Australia. For non-Indigenous residents the proportion employed in the government sector is the same in remote and non-remote areas, signifying Indigenous employment is significantly concentrated in the government sector in remote Australia.

Due to their weak position in the labour market, Roma's income is below average and poverty is widespread. Per capita income in remote areas is around half of the national average, and income of remote villages with Roma

\footnotetext{
${ }^{11}$ However, according to the 2003 national survey, Roma employment and activity rate is characterized by strong regional, urban-rural and gender differences: about 65 per cent of the working-age Roma men in Budapest had regular working opportunity (which is considered to be high even compared with the non-Roma population), while the respective data of working-age Roma women in East Hungary reached only 6 per cent (KEMÉNY, I. and JANKY, B. 2005).
} 
Table 6. Employment indicators of remote areas of Hungary, 2011

\begin{tabular}{c|c|c|c|c|c|c}
\hline \multirow{2}{*}{$\begin{array}{c}\text { Proportion } \\
\text { of Romas in } \\
\text { settlements, \% }\end{array}$} & \multicolumn{2}{|c|}{ Employment rate } & \multicolumn{2}{c|}{ Unemployment rate } & \multicolumn{2}{c}{$\begin{array}{c}\text { Number of public workers } \\
\text { per 100 employed }\end{array}$} \\
\cline { 2 - 7 } & Remote & $\begin{array}{c}\text { Non- } \\
\text { remote }\end{array}$ & Remote & $\begin{array}{c}\text { Non- } \\
\text { remote }\end{array}$ & Remote & $\begin{array}{c}\text { Non- } \\
\text { remote }\end{array}$ \\
\hline $0-1$ & 47.1 & 60.1 & 19.6 & 10.5 & 22 & 3 \\
$1-5$ & 45.3 & 59.9 & 20.7 & 11.9 & 24 & 3 \\
$5-10$ & 43.3 & 51.3 & 22.6 & 17.1 & 26 & 12 \\
$10-20$ & 42.2 & 49.3 & 24.2 & 17.5 & 29 & 15 \\
$20-30$ & 38.7 & 46.3 & 26.7 & 21.1 & 37 & 22 \\
$30-40$ & 33.9 & 39.8 & 31.1 & 26.2 & 52 & 47 \\
40 and over & 25.9 & 29.3 & 45.6 & 33.9 & 97 & 85 \\
Total & 41.5 & 58.9 & 24.5 & 12.0 & 31 & 4 \\
\hline Roma average & \multicolumn{3}{|c|}{44.3} \\
\hline
\end{tabular}

Source: Authors' calculation based on the 2011 Census data.

majority is even less, about 27 per cent (Table 8). Despite the huge differences between remote and non-remote areas as a whole, non-remote localities with Roma majority have almost the same income level as remote ones $(27.4 \%$ and $26.6 \%$ of the national average respectively).

Low income and deep poverty necessarily manifests in low living standards. Data from the 2011 census show that the remote housing density is significantly higher than other areas, while the quality of flats and the availability of internet subscriptions are far below the non-remote and non-Roma average (Table 8). Overcrowding is common for Roma households because of the relatively

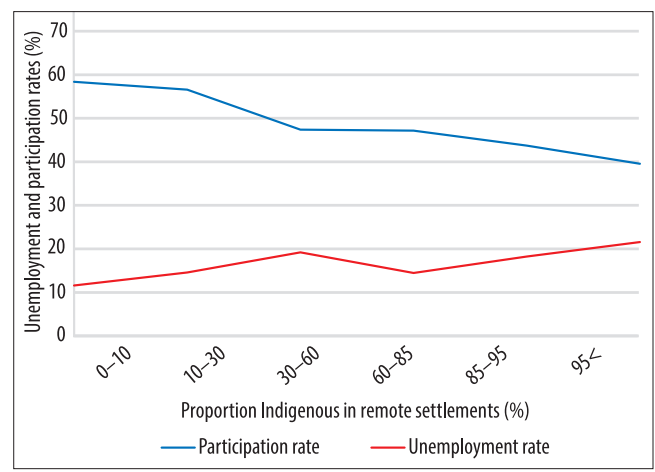

Fig. 7. Unemployment and participation rates in remote settlements, 2011. Source: Author's calculations using data extracted from ABS Table Builder, 2011 Census. high number of children and the small, bad quality of flats. According to the statistics, a low per capita number of internet subscriptions is also inversely correlated to the high Roma share within the local population.

In similarity to Roma people in Hungary, overcrowding is more common in towns where the proportion of Indigenous Australian's in the resident population is higher.

Table 7. Indicators of the proportion of employed persons who work in the government sector ${ }^{*}, 2011$.

\begin{tabular}{l|c|c}
\hline $\begin{array}{c}\text { Proportion } \\
\text { Indigenous } \\
\text { in remote } \\
\text { communities, \% }\end{array}$ & $\begin{array}{c}\text { Number of } \\
\text { communities }\end{array}$ & $\begin{array}{c}\text { Average } \\
\text { per cent } \\
\text { government } \\
\text { employed* }\end{array}$ \\
\hline $0-10$ & 71 & 34 \\
$10-30$ & 57 & 28 \\
$30-60$ & 40 & 32 \\
$60-85$ & 35 & 27 \\
$85-95$ & 112 & 31 \\
$\quad 95$ and over & 89 & 35 \\
Total remote, \\
Indigenous \\
Total remote, Non- \\
$\begin{array}{l}\text { Indigenous } \\
\text { Non-remote, }\end{array}$ \\
$\begin{array}{l}\text { Indigenous } \\
\text { Non-remote, Non- }\end{array}$ \\
Indigenous
\end{tabular}

${ }^{*}$ Government sector includes the Australian State and territory and local governments. Source: Custom data extracted by the authors from ABS Table Builder, 2011 Census. 
Table 8. Income and some indicators of living circumstances in Hungary, 2011

\begin{tabular}{c|c|c|c|c|c|c}
\hline \multirow{2}{*}{$\begin{array}{c}\text { Proportion } \\
\text { of Romas in } \\
\text { settlements, \% }\end{array}$} & \multicolumn{2}{|c|}{$\begin{array}{c}\text { Relative income per capita } \\
\text { (Hungary = 100.0) }\end{array}$} & \multicolumn{2}{c|}{$\begin{array}{c}\text { Share of dwellings with } \\
\text { six or more residents }\end{array}$} & \multicolumn{2}{c}{$\begin{array}{c}\text { Number of internet } \\
\text { subscriptions per 1,000 } \\
\text { persons }\end{array}$} \\
\cline { 2 - 7 } & Remote & $\begin{array}{c}\text { Non- } \\
\text { remote }\end{array}$ & Remote & $\begin{array}{c}\text { Non- } \\
\text { remote }\end{array}$ & Remote & $\begin{array}{c}\text { Non- } \\
\text { remote }\end{array}$ \\
\hline $0-1$ & 58.2 & 105.5 & 3.0 & 2.0 & 251 & 359 \\
$1-5$ & 55.6 & 108.4 & 3.1 & 1.7 & 245 & 369 \\
$5-10$ & 53.7 & 74.1 & 4.0 & 3.0 & 239 & 279 \\
$10-20$ & 51.9 & 71.1 & 5.1 & 4.3 & 238 & 281 \\
$20-30$ & 46.2 & 59.5 & 6.6 & 6.0 & 227 & 256 \\
$30-40$ & 39.5 & 42.8 & 9.0 & 7.3 & 266 & 219 \\
40 and over & 26.6 & 27.4 & 12.0 & 14.1 & 187 & 235 \\
Total & 50.4 & 103.4 & 5.1 & 1.9 & 238 & 356 \\
\hline
\end{tabular}

Source: Authors' calculation based on the 2011 Census data.

There is a strong statistical relationship between the proportion Indigenous in remote towns and the proportion of private dwellings with six or more residents (Figure 8). In remote areas, there are (on average) more persons per bedroom in private dwellings. In Indigenous households in remote Northern Territory, for example, there are an average of 1.5 persons per bedroom and 3.5 persons per household compared to 1.2 persons per bedroom and 2.5 persons per household for non-Indigenous households (ABS 2012b).

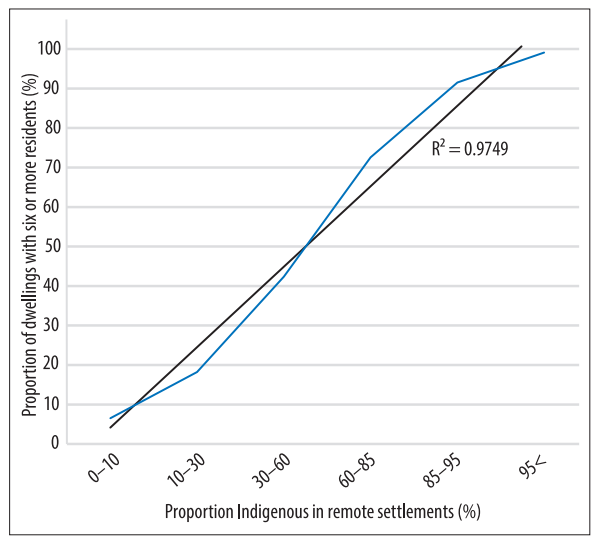

Fig. 8. Dwellings with six or more residents in remote settlements, 2011. Source: Author's calculations using data extracted from ABS Table Builder, 2011 Census.
Meanwhile, internet connection rates in remote settlements are inversely related to the proportion of the population of dwellings which are classified as Indigenous dwellings (Figure 9).

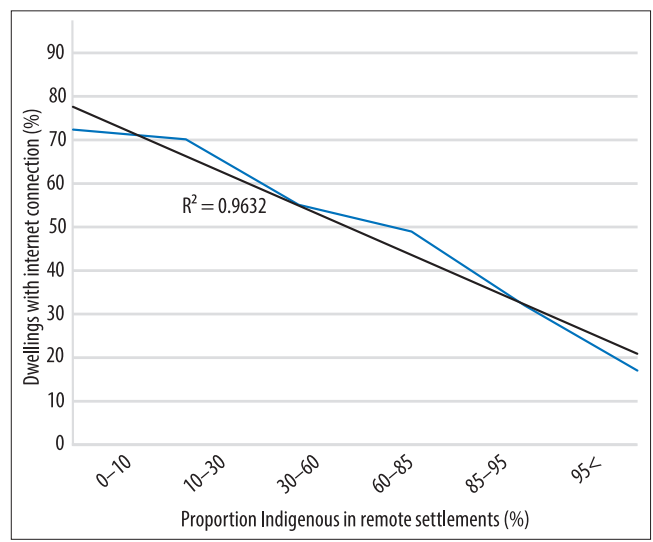

Fig. 9. Proportion of remote dwellings with internet connections, 2011. Source: Author's calculations using data extracted from ABS Table Builder, 2011 Census.

\section{Discussion and conclusions}

In this study we have compared and contrasted a range of demographic, socio-economic and other indicators to highlight the similar circumstances faced by the visible 
minorities of Hungarian Roma and Australian Indigenous peoples. The research here emphasises that, although there are substantial conceptual and methodological issues in directly comparing visible minorities with non-migrant backgrounds, people in both populations face similar issues in terms of their social and economic wellbeing, suggesting that they are in a disadvantaged position and are not benefiting to the extent of wider society. Based on statistical data, the research revealed essential similarities in remote geographical position intertwined with poor socio-economic circumstances of the two groups.

It is important to emphasize that both groups are overrepresented in remote areas which are peripheral and underdeveloped areas of the two countries. The data shows substantial 'gaps' in the selected indicators, namely fertility, health, education, income, labour market, household internet and car ownership. Both Roma and Indigenous people are characterized by unfavourable indicators in these areas compared to the majority of society. Furthermore, the research found gaps not only between the visible minorities and the others but between remote living and non-remote people as well. Overall, therefore, the impoverished position of Roma and Indigenous people can be conceptualised along three dimensions: spatial remoteness, socioeconomic remoteness and ethnic differentiation.

What is special in our case is the spatial factor. In developed countries, most of the visible minorities have a migrant background; tending to settle in urban regions, as most developed places providing propitious life-circumstances, when resettling. By contrast, visible minorities with a non-migrant background are concentrated in regions offering a narrower range of possibilities for wellbeing due to historical processes which have resulted in lower socioeconomic status in these areas. This situation is sometimes exacerbated by unfavourable settlement patterns and ethnic residential segregation.

In Australia gaps between both Indigenous and other Australians, as well as between remote-living and urban-living Australians have become the focus for successive iterations of national and State or Territory government policies for rectifying the situation. While key health indicators, such as infant mortality rates, for remote living Indigenous people are improving (Australian Government 2015), it is difficult to argue that decades of high investment have paid dividends in terms of 'closing the gaps'. Some of this, like the gap in life expectancies between Indigenous Australians and others, is because conditions for others continue to improve, and so despite improvements for Indigenous people, the gaps remain.

In Hungary, the analysis has confirmed the general gap between Roma and non-Roma people by comparing national census data. This gap is also traceable within remote areas where generally, a higher Roma population share means worse indicators at the settlement level. Based on the few available data and the general gap between the remote and non-remote areas, and considering the limits of the indirect method, we also argue that remote living Roma face somewhat worse life-circumstances than their co-ethnics in non-remote regions. Similar to the Australian case, despite the governmental policies (mostly employment and education policies) addressing 'closing the gaps' between Roma and non-Roma following the regime change in 1989, Roma life circumstances have barely improved and, thus, the gaps remained or continued to grow (Molnár, E. and DupcsiK, C. 2008; FleCK, G. and Messing, V. 2010; Kertesi, G. and Kézdi, G. 2012).

The reasons for the gaps are mostly derived from visible minorities' inherited social and spatial disadvantage. During the formation of modern societies, non-migrant visible minorities were pushed to the geographical peripheries, excluded from the traditional society (or if integrated, only to the bottom strata) and secluded from the resources. Social and spatial marginalization was facilitated by their 'visibility', i.e. the racial differentiation. Up to the 1970s in Australia and until 1989 in Hungary, the contemporary power 
made efforts to resolve Indigenous/Roma issue by forced assimilation. In recent decades, policies of multiculturalism are favouring visible minorities, however with little effect, therefore both Indigenous Australians and Hungarian Roma still suffer from low socialpolitical-economic integration, low human capital and low accessibility to resources. Ethnic discrimination and remote geographical position also contributes to unequal social relations and exclusion from the centralized decision-making process.

A lack of human capital and financial resources also hampers mass migration of Roma and Indigenous to non-remote areas, which might be the easiest way to 'break out' of poverty. Nevertheless, numerous examples show that individuals with capacity for social mobility can successfully improve their socioeconomic status. However, these "success stories" more likely result in assimilation, especially if the individuals' anthropologic character allows getting out from Indigenous/Roma ethnic category. Overall, as a consequence of the changing ethnic selfidentification of wealthy members of visible minorities, only poor, marginalized people likely living in remote areas will be associated with non-migrant visible minorities.

Our study is an attempt to conceptualise international comparisons of visible minorities focusing on remote living Hungarian Roma and Australian Indigenous. We found that, independent from the geographical location, the scale and the social context, visible minorities face similar problems and gaps, and patterns of social and spatial exclusion are similar across the developed nations. Policy makers will benefit from understanding marginalization and disadvantage of minority groups through the lenses applied in this study to formulate policies for improving these circumstances across international boundaries.

Acknowledgement: Patrik TÁTRAI's research was supported by the János Bolyai Research Scholarship of the Hungarian Academy of Sciences.

\section{REFERENCES}

ABS 2007. Discrete Indigenous Communities \& Australian Geographical Classification Remoteness Structure. Canberra, Australian Bureau of Statistics. http://www.ausstats.abs.gov.au/ausstats/subscriber.nsf/0/499711EC612FF76ECA2574520010E1 FE/\$File/communitymap.pdf. Accessed 20.09.2017 ABS 2012a. 3302055003DO002_20102012 Life Tables for Aboriginal and Torres Strait Islander Australians, 2010-2012. www.abs.gov.au. Accessed 23.03.2015. ABS 2012b. 2002.0-Aboriginal and Torres Strait Islander Peoples (Indigenous) Profile. Canberra, Australian Bureau of Statistics.

ABS 2013a. 2077.0 - Census of Population and Housing: Understanding the Increase in Aboriginal and Torres Strait Islander Counts, 2006-2011. www.abs.gov.au Accessed. 16.04.2016.

ABS 2013b. 3302055003DO002_20102012 Life Tables for Aboriginal and Torres Strait Islander Australians, 2010-2012. www.abs.gov.au. Accessed 23.03.2015.

ABS 2015. 3101.0 - Australian Demographic Statistics, Jun 2015.http://www.abs.gov.au/ausstats/abs@.nsf/ $\mathrm{mf} / 3101.0$. Accessed 13.03.2016.

ABS 2016. 2011 Census QuickStats. http://www.censusdata.abs.gov.au/census_services/getproduct/census/2011/quickstat/0?opendocument\&navpos=220. Accessed 26.08.2016.

Abu-SaAd, I. and Creamer, C. 2012. Socio-Political Upheaval and Current Conditions of the Naqab Bedouin Arabs. In: Indigenous (In)Justice. Eds.: Amara, A., Abu-Saad, I. and Yiftachel, O., Cambridge, Harvard University Press, 18-66.

AIHW (Australian Institute of Health and Welfare) 2014. Mortality and life expectancy of Indigenous Australians: 2008 to 2012. Canberra, Australian Institute of Health and Welfare.

Australian Government 2015. Closing the Gap: Prime Minister's Report 2015. Canberra, Commonwealth of Australia.

Australian Population and Migration Research Centre 2014. ARIA (Accessibility/Remoteness Index of Australia). http://www.adelaide.edu.au/apmrc/research/projects/category/about_aria.html. Accessed 03.10.2014.

BAbusik, F. 2004. Állapot-, mód- és okhatározók. A romák egészségügyi állapota és az egészségügyi szolgáltatásokhoz való hozzáférése I. (The health status of the Roma and their access to health care I). Beszélő, 9. (10): 84-93.

Bock, B., Kovacs, K. and Sнucкsmith, M. 2014. Changing social characteristics, patterns of inequality and exclusion. From rural development to rural territorial cohesion. In Territorial cohesion in rural Europe: the relational turn in rural development. Eds.: Copus, A.K. and DE Lima, P., New York, Routledge, 193-205. 
Csepeli, G. and Simon, D. 2004. Construction of Roma Identity in Eastern and Central Europe: Perception and Self-identification. Journal of Ethnic and Migration Studies 30. (1): 129-150.

Durst, J. 2010. "What Makes Us Gypsies, Who Knows...?!": Ethnicity and Reproduction. In Multidisciplinary Approaches to Romany Studies. Eds.: Stewart, M. and Rövid, M., Budapest, CEU Press, 13-34.

EC 2014. Roma Health Report. Health status of the Roma population. Data collection in the Member States of the European Union. European Commission. http:// ec.europa.eu/health/social_determinants/docs/2014 roma_health_report_en.pdf. Accessed 18.04.2016.

FAluvéGI, A. and Tipold, F. 2012. A társadalmi, gazdasági és infrastrukturális szempontból elmaradott, illetve az országos átlagot jelentősen meghaladó munkanélküliséggel sújtott települések (Socially, economically and infrastructurally disadvantaged settlements, and those with high unemployment). Területi Statisztika 15. (3): 278-290.

Feischmidt, M. 2012. Constraints and Accommodation. Economic and Symbolic strategies of Romani people living in Hungarian villages. In Identities, Ideologies and Representations in Post-transition Hungary. Eds.: Heller, M. and KRIZA, B., Budapest, ELTE Eötvös Kiadó, 259-290.

FleCK, G. and Messing, V. 2010. Transformations of Roma employment policies. In The Hungarian Labour Market 2010: Review and Analysis. Eds.: Lovász, A. and Teleggdy, Á., Budapest, Insitute of Economics, HAS \& National Employment Foundation, 83-98.

FónaI, M., Fábián, G., Filepné Nagy, É. and Pénzes, M. 2008. Poverty, health and ethnicity: The empirical experiences of researches in Northeast-Hungary. Review of Sociology of the Hungarian Sociological Association 14. (2): 63-91.

Galabuzi, G. 2006. Canada's economic apartheid: The social exclusion of racialized groups in the new century. Toronto, Canadian Scholars' Press.

Gregory, R. and Daly, A. 1997. Welfare and Economic Progress of Indigenous Men of Australia and the U.S.: 1980-1990. Economic Record 73. 101-119.

HablicseK, L. 2008. The Development and the Spatial Characteristics of the Roma Population in Hungary Experimental Population Projections till 2021. Demográfia 51. (5): 85-123.

Havas, G., Kemény, I. and Kertesi, G. 2000. A relatív cigány a klasszifikációs küzdőtéren (The relative Roma in the classification struggle). In Cigánynak születni. Tanulmányok, dokumentumok. Eds.: HoRvátH, Á., Landau, E. and Szalai, J., Budapest, Aktív Társadalom Alapítvány \& Új Mandátum Kiadó, 193-201.

Hoddie, M. 2006. Ethnic Realignments. A Comparative Study of Government Influences on Identity. Lenham, Lexington Books.
Hou, F. and Рiсот, G. 2004. Profile of ethnic origin and visible minorities for Toronto, Vancouver, and Montreal. Canadian Social Trends 11. 9-14.

JANKY, B. 2006. The Social Position and Fertility of Roma Women. In Changing Roles. Eds.: NAGY, I., Pongrácz, T. and TóTH, I., Budapest, TÁRKI, 136-150.

Kemény, I. and Janky, B. 2005. Roma Population of Hungary 1971-2003. In Roma of Hungary. Ed.: KemÉny, I., Highland Lakes, Atlantic Research and Publication, 70-225.

Kertesi, G. and Kézdi, G. 2012. Ethnic segregation between Hungarian schools: Long-run trends and geographic distribution. Budapest, Institute of Economics, RCERS, HAS \& Department of Human Resources, Corvinus University of Budapest.

KIM 2011. Nemzeti társadalmi felzárkózási stratégia - mélyszegénység, gyermekszegénység, romák-(2011-2020) (National Social Inclusion Strategy - extreme poverty, child poverty, Romas - [2011-2020]). Budapest, Ministry of Public Administration and Justice, Hungary http://romagov.kormany.hu/download/8/ e3/20000/Strat\%C3\%A9gia.pdf

Klinger, A. 2003. Mortality differences between the subs regions of Hungary. Demográfia 46. (5): 21-53.

Kocsis, K. and Kovács, Z. 1991. A magyarországi cigány népesség társadalomföldrajza (The social geography of the Gypsy population in Hungary). In Cigánylét. Eds.: Utasi, A. and Mészáros, Á., Budapest, MTA Politikai Tudományok Intézete, 78-105.

LadÁnyi, J. and Szelényi, I. 2001. The Social Construction of Roma Ethnicity in Bulgaria, Romania and Hungary during Market Transition. Review of Sociology of the Hungarian Sociological Association 7. (2): 79-89.

LadÁNyI, J. and SzelÉNyI, I. 2006. Patterns of Exclusion: Constructing Gypsy Ethnicity and the Making of an Underclass in Transitional Societies of Europe. New York, Columbia University Press.

LADÁNYI, J. and ViráG, T. 2009. A szociális és etnikai alapú lakóhelyi szegregáció változó formái Magyarországon a piacgazdaság átmeneti időszakában (Forms of social and ethnic segregation in Hungary during the market transition period). Kritika 38. (7-8): 2-8.

LANG, T. 2015. Socio-economic and political responses to regional polarisation and socio-spatial peripheralisation in Central and Eastern Europe: a research agenda. Hungarian Geographical Bulletin 64. (3): 171-185.

LeE, K.W. 2011. A comparison of the health status of European Roma and Australian Aborigines. Ethnicity and Inequalities in Health and Social Care 4. (4): 166-185.

Lócsei, H. and SzalkaI, G. 2008. Helyzeti és fejlettségi centrum-periféria relációk a hazai kistérségekben (Role of location and development in the centreperiphery relations in the Hungarian subregions). Területi Statisztika 11. (3): 305-314. 
Milcher, S. 2006. Poverty and the Determinants of Welfare for Roma and Other Vulnerable Groups in Southeastern Europe. Comparative Economic Studies 48. (1): 20-35.

Molnár, E. and Dupcsik, C. 2008. Country Report on Education: Hungary. Budapest, Center for Policy Studies, CEU.

NAGY, E. 2015. Discussing inequalities from the periphery. Hungarian Geographical Bulletin 64. (3): 167-170.

PÁsztor, I.Z. and Pénzes, J. 2012. Employment crisis and income peripherization in Northeastern Hungary with special attention to the Roma population. In Roma Population on the Peripheries of the Visegrad Countries. Eds.: Pénzes, J. and Radics, Z., Debrecen, Didakt, 52-65.

PÁsztor, I.Z., Pénzes, J., Tátrai, P. and Pálóczi, Á. 2016. The number and spatial distribution of the Roma population in Hungary - in the light of different approaches. Folia geographica, Acta facultatis studiorum humanitatis et naturae Universitatis Prešoviensis 58. (2): 5-21.

Pedersen, A. and Walker, I. 1997. Prejudice against Australian Aborigines: old-fashioned and modern forms. European Journal of Social Psychology 27. (5): 561-587.

Pénzes, J. 2013. The dimensions of peripheral areas and their restructuring in Central Europe. Hungarian Geographical Bulletin 62. (4): 373-386.

Pénzes, J., Tátrai, P. and PÁsztor, I.Z. 2018. A roma népesség területi megoszlásának változása Magyarországon az elmúlt évtizedekben (Changes in the spatial distribution of the Roma population in Hungary during the last decades). Területi Statisztika 58. (1): 3-26.

Rowse, T. 2006. Towards a history of Indigenous statistics in Australia. In Assessing the Evidence on Indigenous Socioeconomic Outcomes: A Focus on the 2002 NATSISS. Ed.: Hunter, B.H., Canberra, Centre for Aboriginal Economic Policy Research, The Australian National University, 1-10.
TÁtrai, P. 2015. Transformations of the ethnic structure in Hungary after the turn of the millennium. Human Geographies 9. (1): 79-96.

TÁtrai, P., PÁlóczi, Á., PÁsztor, I.Z. and Pénzes, J. 2017. Etnikai besorolási gyakorlatok: a cigányság külső kategorizálását befolyásoló tényezők (Contributions to the background of external categorization of Roma). Socio.hu Társadalomtudományi Szemle 7. (2): 44-64.

TAylor, A. and Bell, B. 2013. The Northern Territory's declining share of Australia's Indigenous population: A call for a research agenda. Darwin, Charles Darwin University.

Taylor, A., Larson, S., Stoeckl, N. and Carson, D. 2011. The haves and have nots in Australia's Tropical north - new perspectives on a persisting problem. Geographic Research 49. (1): 13-22.

Uzzoli, A. and SzILÁGYi, D. 2009. Life expectancy and its regional inequalities in Hungary. Geographica Pannonica 13. (4): 127-136.

VIrág, T. 2006. The regional ghetto. Review of Sociology of the Hungarian Sociological Association, 12. (1): 51-70.

WANG, J-H. 2015. Happiness and Social Exclusion of Indigenous Peoples in Taiwan - A Social Sustainability Perspective. PLoS ONE 10. (2): e0118305.

White, P.A. 2008. The Hot Seat: The Black Scholar's Perception of the "Chilly Climate". In Whose University is It, Anyway?: Power and Privilege on Gendered Terrain. Eds.: Acker, S., Wagner, A. and Mayuzumi, K., Toronto, Sumach Press, 79-89. 